
\title{
25 Research Square \\ Comparative Study of Hot Air Drying and Microwave Drying for Dewatered Sludge
}

\section{Wittawat Wulyapash}

Joint Graduate School of Energy and Environment

Awassada Phongphiphat ( $\square$ awassada.pho@kmutt.ac.th )

Joint Graduate School of Energy and Environment https://orcid.org/0000-0003-4974-920X

Sirintornthep Towprayoon

Joint Graduate School of Energy and Environment

\section{Research Article}

Keywords: Sludge, Microwave drying, Hot air drying, Refuse derived fuel, Waste-to-energy

Posted Date: March 15th, 2021

DOI: https://doi.org/10.21203/rs.3.rs-178542/v1

License: (c) (1) This work is licensed under a Creative Commons Attribution 4.0 International License.

Read Full License

Version of Record: A version of this preprint was published at Clean Technologies and Environmental

Policy on November 30th, 2021. See the published version at https://doi.org/10.1007/s10098-021-022425 . 


\section{Abstract}

Large amounts of sludge are generated from wastewater treatment in seafood processing industries. Most of the dewatered sludge in Thailand is not utilized and disposed by landfilling. The dried sludge utilization as refuse-derived fuel (RDF) is an alternative solution due to the gross calorific value (GCV), which is greater than $21.9 \mathrm{MJ} / \mathrm{kg}$. However, the key obstacle is its high moisture content of $87.4 \%$ (wet basis). Therefore, drying methods using hot air and microwave techniques were investigated for preparing dried sludge. The effects of hot air temperatures $\left(100-150^{\circ} \mathrm{C}\right)$ and microwave power levels (100-800 W) were compared on drying kinetics, specific energy consumption (SEC), and characteristics of the dried products. The results showed that drying times were decreased by increasing the hot air temperatures. In the same way, the increase in microwave power levels decreased the drying time. The application of microwaves contributed to reducing the drying time by more than $46 \%$ compared to the hot air. The reduction of drying times resulted in the saving SEC. The GCV of the dried sludge decreased with the decrease in the volatile matter (VM) due to the high component of VM as $79.5-80.3 \%$ (dry ash-free basis). The sludge dried by the microwaves showed a lower GCV than the hot air products. However, dried sludges still had high GCV ( $\geq 20.8 \mathrm{MJ} / \mathrm{kg}$ ). Furthermore, the minimal variation of the product characteristics demonstrated that the microwave technique could be applied as an alternative drying method with a rapid process compared to the conventional hot air technique.

\section{Introduction}

Thailand is one of the world's leading seafood producers. For the tuna business alone, Thailand contributes to $33.2 \%$ of the world's export value for tuna products. The products were exported about 710,962 tons, generating 2,826 million dollars of income in 2019 (Thai tuna industry association 2020). This business has also created jobs for local communities. With support from government policies, the food processing industry continues to expand and will remain important in our country. Unfortunately, most food processing industries generate a huge amount of wastewater as well as sludge from their treatment plant. Common sludge management in Thailand is started from thickening and dewatering processes, after that the dewatered sludge is sent to landfills. The landfilling of sludge is widely used in Thailand because it is simple. However, it could be costly due to the transportation and tipping fee, also it becomes non value-added waste.

Generally, dried sludges have a gross calorific value (GCV) of 14-23 MJ/kg (He et al. 2013; Mawioo et al. 2017; Poudel et al. 2015), comparable to lignite 12-25 MJ/kg (Arlabosse et al. 2011; Syed-Hassan et al. 2017; Zhang et al. 2016), and bituminous 21-29 MJ/kg (ASTM International 2019; Syed-Hassan et al. 2017). The calorific value aspect reveals that dried sludge utilization as solid fuels in thermochemical processes is an attractive management solution. Produced refuse-derived fuel (RDF) from sludge can be used as single fuel or co-combustion with fossil fuels (imported coal, fuel oil) commonly fed the industry's boilers (Bennamoun et al. 2016a; Lu et al. 2013; Nzihou 2020). However, one of the key obstacles in utilizing sludge as RDF is its high moisture. The general dewatered sludge still has a high moisture content of 73-89 \% (wet basis) (Syed-Hassan et al. 2017). Therefore, a proper drying process is 
necessary for preparing dried sludge before energetic utilization as alternative solid fuel. In addition, the drying could help to reduce the volume of sludge and decreases the cost of handling, transport, and storage of the dried product.

Conventional drying of sludge is usually performed by a convective technique using hot air as drying media. The hot air temperature of sludge drying could be obtained around $60-180{ }^{\circ} \mathrm{C}$ depending on the thermal degradation characteristics of raw sludge (Tańczuk et al. 2016; Zhang et al. 2016). Many types of convective driers are applied in industries, such as belt dryers, flash dryers, and drum dryers. The specific energy consumption (SEC) of the convective dryer varies 2.5-5.0 MJ/kg of evaporated water (Arlabosse et al. 2011). Hot air drying is widely used in any industrial sector due to the uncomplicated operation. However, the conventional hot air drying of sludge is energy-intensive and time-consuming due to its high moisture content (Syed-Hassan et al. 2017). During the drying, the moisture content is gradually decreased because both heating and water evaporation almost take place at the surface of a material (Mounir et al. 2019). To overcome this drawback, microwave drying could be an alternative technique for reduced drying time, which results in save energy consumption and increase loading capacity.

The main difference between the hot air and microwave drying processes is the heating mechanism (Mounir et al. 2019). Microwaves generate heat both internally and at the surface of the treated materials by oscillatory electric fields. When applying microwave on moist materials, microwave energy is absorbed by the dielectric properties of water and converted into heat within the volume of material. The material is heated rapidly, resulting in an increase in evaporation rate during the drying process (Barbosa de Lima et al. 2016; Gaukel et al. 2017). The volume of raw sludge can be reduced to over $60 \%$ and a high level of dry matter in the dried sludge was achieved (up to 98\%) (Mawioo et al. 2017). The final temperature of a material is a key impacting factor, which affects the product properties in microwave heating. In the study by Wang et al. (2015), microwave pretreated sludge at $100{ }^{\circ} \mathrm{C}$ effectively released nitrogen up to 4.61 $\mathrm{mg} / \mathrm{g}$ (dry basis). Liu et al. (2017) reported microwave treatment over $220^{\circ} \mathrm{C}$ influences the dechlorination of organochloride waste mixture as chlorine removal of $87 \%$.

Hot air and microwave drying have been widely studied in many fields of research, especially food science and postharvest technology. However, studies on sludge and waste treatment are still very limited, especially microwave drying. Bennamoun et al. (2016b) studied forced convective drying of wastewater sludge under air temperatures of 80,140 , and $200{ }^{\circ} \mathrm{C}$ and air velocity of $1-2 \mathrm{~m} / \mathrm{s}$. The increase in drying temperature results in the improved drying kinetic of the sludge. The optimum drying condition is a drying temperature of $140^{\circ} \mathrm{C}$ with an air velocity of $2 \mathrm{~m} / \mathrm{s}$ due to an exergy efficiency reaching $90 \%$. (Zhang et al. 2016) studies drying of sludge and sludge mixed lignite briquettes under drying temperatures of $60-180{ }^{\circ} \mathrm{C}$ and air velocity of $1.5 \mathrm{~m} / \mathrm{s}$. The average drying rates of the mixed sample are $\geq 2.6 \%$ higher than the raw sludge. Drying temperatures over $120^{\circ} \mathrm{C}$ indicate the effective moisture diffusivities of the sludge briquettes. Li et al. (2015) studied convective drying of sludge mixed sawdust under drying temperatures of 50,80 , and $110{ }^{\circ} \mathrm{C}$ and fixed air velocity at $2 \mathrm{~m} / \mathrm{s}$. Sludge mixed sawdust shows a negative impact on the drying process. The mixed material indicates the drying rate 
lower than the original sludge. The maximum drying time is about $5.5 \mathrm{~h}$ for a drying temperature of 50 ${ }^{\circ} \mathrm{C}$. Bennamoun et al. (2016a) studied microwave drying of wastewater sludge under different power levels between 480 and $1,080 \mathrm{~W}$. The results show that microwave drying reduces the drying time by around $93 \%$ compared with convective drying. An increase in power level results in the drying rate decreases. The maximum temperature of the sludge reaches $140^{\circ} \mathrm{C}$ during microwave drying. The shrinkage of sludge reduces the volume up to $42 \%$, which is less than the shrinkage of convective drying. Mawioo et al. (2017) studied microwave drying in a pilot-scale reactor at a power of $3.4 \mathrm{~kW}$ using four different types of sludge. The results indicate that the temperature increment of sludge is inversely related to the moisture content. The maximum temperature of sludge during the process is $102{ }^{\circ} \mathrm{C}$. The dried products have the potential to be producing solid fuel with a GCV of $16-23 \mathrm{MJ} / \mathrm{kg}$. Each batch test was started with a cold reactor that caused higher SEC as 10-16 MJ/kg of evaporated water. Several studies have investigated on characteristics of dried products and the efficiency of drying method. However, the comparison on the fuel characteristics of sludge dried by hot air and microwave techniques is limited. The objective of this study is, therefore, to investigate sludge drying under microwave and hot air techniques, and to compare the drying kinetics and the characteristics of the dried sludge.

\section{Materials And Methods}

\section{Materials}

The dewatered sludge was collected from a belt filter press machine of a wastewater treatment system located in a seafood processing plant at Samut Sakhon, Thailand. To preserve the drying properties of the sludge, the sample was thoroughly mixed and stored at $-2^{\circ} \mathrm{C}$ in closed plastic containers (Darvishi et al. 2013; Zhang et al. 2016). Before testing, the sludge was removed from the freezer and allowed to return to ambient temperature within the container in order to maintain moisture content (Fennell and Boldor 2014).

\section{Experimental setup and procedures}

The sludge drying was performed under two different methods of hot air and microwave techniques. The effects of hot air and microwave on the sludge characteristics and drying kinetics were investigated under different experimental conditions. The ambient temperature and relative humidity, which were measured by a thermo-hygrometer (Testo, 605i, USA), during the drying period were around $30^{\circ} \mathrm{C}$ and $67 \%$, respectively. A drying experiment of the hot air technique was conducted using a laboratory hot air oven (Scientific series 9000, 973, Norway). Downdraft ventilation of the oven was set to promote moisture removal from the surface of the sample. The air velocity was fixed at $6.5 \mathrm{~m} / \mathrm{s}$, which was measured by a vane anemometer (Testo, $410 \mathrm{i}$, USA). The thermal treatment at a higher temperature of the sludge results in devolatilization and combustion (He et al. 2013; Poudel et al. 2015; Yu and Li 2014; Záleská et al. 2017). Therefore, the experimental conditions concerning the thermal degradation were studied at air temperatures of 100,125 , and $150^{\circ} \mathrm{C}$ in two different thicknesses of the sludge layer as 1 and 2 inches. Each experimental condition was performed in quadruplicate to ensure the data and the 
average values were reported. The drying of the sludge by microwave technique was performed in a domestic microwave oven (Electrolux, EMM2301W, China) with a capacity of $23 \mathrm{I}$. The microwave cavity has a rectangular shape with the interior dimensions of $31.4 \mathrm{~cm} \times 22.1 \mathrm{~cm} \times 34.7 \mathrm{~cm}$. The microwave generator has a maximum power output of $800 \mathrm{~W}$ at a frequency of $2450 \mathrm{MHz}$. Four microwave power levels of $100,400,600$, and $800 \mathrm{~W}$ were investigated. The sludge was placed in a ceramic dish $20 \mathrm{~cm}$ in diameter. The thickness of the sample in the dish was approximately 1 inch. Microwaves at a frequency of $2450 \mathrm{MHz}$ have a penetration depth of $0.4-1.9$ inches when applied on wastewater sludge (Hong et al. 2006; Karlsson et al. 2019; Mokhtar et al. 2011). Increasing the sludge thickness and moisture content could reduce the efficiency of microwave absorption and volumetric heating of the material. The initial sample weight was $400 \mathrm{~g}$ for each experiment. The mass monitoring of samples was referred to the weighing method as described by Villagracia et al. (2016). The instantaneous weight of the sludge was measured using a precision balance (Sartorius, BP4100S, Germany), which has an accuracy of $\pm 0.01 \mathrm{~g}$, every $10 \mathrm{~min}$ for the microwave drying and $60 \mathrm{~min}$ for the hot air drying. At the same time, the surface temperature of the sludge was measured using an infrared thermometer (Testo, 805i, USA) with an accuracy of $\pm 1.5^{\circ} \mathrm{C}$. The thermometer was connected to a smartphone via "testo Smart Probes" application for the data record. The sludge was dried until reached the bone-dried mass. The dried samples were kept in plastic zip bags and stored in a desiccator prior to property analyses.

\section{Analytical methods}

Thermal and chemical properties of the raw sludge and dried products are important to study the characteristic variation that reflects the performance between the hot air and microwave techniques. The initial moisture content of the dewatered sludge was analyzed base on ASTM D3173/D3173M-17a (2017). The samples were dried at $105^{\circ} \mathrm{C}$ until a constant mass (almost $24 \mathrm{~h}$ ) by using a hot air oven (Scientific series 9000,973 , Norway). The dried sludge from the standard method was analyzed ignition temperature, burnout temperature, thermal degradation and combustion behaviors using thermogravimetric analysis (TGA). The TGA was conducted by a thermogravimetric analyzer (Mettler Toledo, TGA 2, UK). The testing condition was carried out in a nitrogen atmosphere under a flow rate of $50 \mathrm{ml} / \mathrm{min}$. The heating steps were set by (I) heating from $30^{\circ} \mathrm{C}$ to $110^{\circ} \mathrm{C}$ with a heating rate of $10^{\circ} \mathrm{C} / \mathrm{min}$, (II) holding for $10 \mathrm{~min}$ at $110^{\circ} \mathrm{C}$, (III) heating from $110^{\circ} \mathrm{C}$ to $900^{\circ} \mathrm{C}$ with a heating rate of $10^{\circ} \mathrm{C} / \mathrm{min}$, and (IV) switching the gas from nitrogen to air under a flow rate of $50 \mathrm{ml} / \mathrm{min}$, and holding for $20 \mathrm{~min}$ at $900^{\circ} \mathrm{C}$. Furthermore, the dried sludges from the microwave and hot air techniques as well as the standard method were analyzed GCV, proximate and elemental characteristics. The GCV analysis was done by a bomb calorimeter (LECO, model AC350) using benzoic acid as a reference standard. Proximate analysis for volatile matter (VM), fixed carbon (FC), and ash content were analyzed by a thermogravimetric analyzer (PerkinElmer, Pyris 1 TGA, USA). The testing condition was set as the same as the mentioned TGA. Elemental analysis for $\mathrm{C}, \mathrm{H}, \mathrm{N}$ content was based on the standards of WI-03 and ASTM D5373-16 (2016) by using an elemental analyzer (J-science, JM10 Micro, Japan). The content of S in the sludge was measured by a carbon sulphur analyzer (Horiba, Emia-220 V2, Japan) under the condition of high-frequency induction furnace. The content of $\mathrm{O}$ was calculated from a hundred percent minus by total amount of $\mathrm{C}, \mathrm{H}, \mathrm{N}, \mathrm{S}$ content. 


\section{Calculation of moisture ratio}

The moisture ratio (MR) of the sample during the processes was calculated as follow Eq. (1). When a comparison of different drying kinetics curves is necessary, the ordinate of the curve is usually the ratio of the moisture content (dry basis) at the drying time (Devahastin 2012).

$$
\mathrm{MR}=\frac{M_{\mathrm{t}}-M_{\mathrm{e}}}{M_{\mathrm{i}}-M_{\mathrm{e}}}
$$

where $M_{\mathrm{t}}$ denotes the moisture content (g water/g dry solid) measured at drying time $\mathrm{t}, M_{\mathrm{e}}$ is the equilibrium moisture content ( $\mathrm{g}$ water/g dry solid), and $M_{\mathrm{i}}$ is the initial moisture content ( $\mathrm{g}$ water/g dry solid). The equilibrium moisture content was assumed to be constant as zero in each drying condition due to the equilibrium moisture content of the dried sample being very low compared to the initial moisture content of the sample (Palamanit et al. 2019; Zohrabi et al. 2019).

\section{Specific energy consumption}

The energy consumption of the drying systems by the hot air and microwave ovens was measured in terms of the electric energy consumption using an energy meter (Electan, ET-MP01U, China). The energy efficiency of each drying condition was calculated in terms of SEC as follows Eq. (2) (Apinyavisit et al. 2017; Darvishi et al. 2013). The SEC was expressed in MJ of total supplied electrical energy per $\mathrm{kg}$ of the total amount of water evaporated from sludge.

$\mathrm{SEC}=\frac{E_{\mathrm{t}} \times 3.6}{\left(M_{\mathrm{t}}-M_{\mathrm{i}}\right) \times m_{\mathrm{s}}}$

where $E_{\mathrm{t}}$ is the electrical power consumption $(\mathrm{kWh})$ of the dryer system at drying time $t$, that the moisture content of sludge reached a target of the final moisture content, and $m_{s}$ is the mass of the dry solid.

\section{Statistical analysis}

Statistical analyses of the experimental data were calculated using Microsoft Excel software. The significant difference of the investigated parameters was analyzed by one-way analysis of variance (ANOVA) at a confidence level of $95 \%$ (P-value $<0.05)$. In each experimental condition, the data was computed mean values and standard deviations. The results in graphs were presented as a mean value.

\section{Results And Discussion}

\section{Characteristics of the raw sludge}

Characteristics of the sludge sample, including moisture content, proximate analysis, elemental analysis, and GCV, are shown in Table 1. The results showed that even though sludge was dewatered by a belt filter press machine, the moisture content still high at $87.40 \%$ (wet basis). However, when it dried, the GCV of 
the sludge is about $22 \mathrm{MJ} / \mathrm{kg}$ that is in about the same range as other sludge and bituminous as 14-23 MJ/kg (He et al. 2013; Mawioo et al. 2017; Poudel et al. 2015) and 21-29 MJ/kg (ASTM International 2019; Syed-Hassan et al. 2017) respectively. The elemental analysis results revealed that the carbon content in the sludge was much higher than the other elements $(\mathrm{H}, \mathrm{N}, \mathrm{S}$, and $\mathrm{O})$. Carbon content in sludge generally varies from 23.3 to 51.7 \% (Syed-Hassan et al. 2017). The main proximate fraction in sludge is a volatile matter (73.04 \%), but low fixed carbon (15.77\%). The sludge could be ignited at low temperatures because of the easy ignition of the volatile components, so the main decomposition process is reasonably held on the devolatilization and combustion phase (Yu and Li 2014). The fuel characteristic results have demonstrated that the sludge has the advantages of looking forward as the solid fuel conversion as RDF. However, the ash content of sludge could be problematic, because it is higher than bituminous of 6.1-8.3 \% (Jong and Ommen 2015; Phongphiphat et al. 2020).

\section{Thermogravimetric analysis}

The thermal behavior of the sludge can be identified from thermogravimetric (TG) analysis. The TG and derivative thermogravimetric (DTG) curves of the sludge are presented in Fig. 1. As offered by KijoKleczkowska et al. (2016), the curve of weight loss by temperature variation be able to divide into 3 zones of (I) evaporation, (II) devolatilization, and (III) combustion. The TG and DTG curves display that devolatilization begins at $120^{\circ} \mathrm{C}$, and at a temperature around $180^{\circ} \mathrm{C}$ shows the inception of intensive thermal degradation. The results indicate that the first phase of decomposition, attributing to the dehydration and drying process, occurred up to $180^{\circ} \mathrm{C}$ (Záleská et al. 2017). The ignition temperature $\left(T_{\mathrm{i}}\right)$ and burnout temperature $\left(T_{b}\right)$ of the sludge are 200 and $510^{\circ} \mathrm{C}$, respectively, which are in the range of the ignition and burnout temperatures of sludge as $230-291^{\circ} \mathrm{C}$ and $455-664^{\circ} \mathrm{C}$, respectively (He et al. 2013; Parshetti et al. 2013; Yu and Li 2014). When sludge is ignited, the main decomposition processes begin with the combustion of volatile matter and complex organic structures. The DTG curve is shown the major peaks at the temperature interval of $265-340{ }^{\circ} \mathrm{C}$. The peak values indicate two maximumdegradation temperatures of the sludge at 270 and $310^{\circ} \mathrm{C}$. The maximum-degradation temperatures are owing to the combustion of volatile matter (Lu and Chen 2015). The high devolatilization indicated that volatile matter played a major role in the thermal behavior of sludge.

\section{Drying kinetics of sludge}

The drying kinetics of sludge during drying with hot air and microwave technique are shown in Fig. 2 and Fig. 3, respectively. The results show that the drying time of the microwave technique was shorter than the drying time of the hot air technique. The drying time of the microwave technique of $100,400,600$, and $800 \mathrm{~W}$ were $300,50,40$, and $30 \mathrm{~min}$, which were decreased with the increasing microwave power, respectively. The drying time of the hot air technique of 150,125 , and $150{ }^{\circ} \mathrm{C}$ were $11,13,15 \mathrm{~h}$ for 1 inch of layer thickness, and 20, 21, 22 h for 2 inches of layer thickness, respectively. As expected, the higher hot air temperature and lower layer thickness provided shorter drying time, because the decrease in layer thickness and increase in drying temperature enhanced the drying rate (Jafari et al. 2017; Palamanit et al. 2019). Comparison between hot air and microwave techniques found that the microwave technique 
saved time more than $46 \%$. For example, the longest drying time of the microwave technique of $100 \mathrm{~W}$ was reduced $6 \mathrm{~h}$ from the shortest time of the hot air technique of $150^{\circ} \mathrm{C}$. The moisture ratio of sludge under microwave technique decreased to the final moisture content faster than hot air technique, because microwave radiation rapidly heats the material from the inside out that accelerates the moisture transfer and drying rate of the material (Bundhoo 2018). In the hot air technique, the drying phases are relatively longer than microwave drying (Bennamoun et al. 2016a). The heat is transferred from the hot air to the surface of materials by convection. The temperature of materials is slowly increased and stayed as the wet-bulb temperature of hot air during the constant rate period of the drying process. In the falling rate period, material temperature increases until it reaches the dry-bulb temperature of the hot air (Devahastin 2012).

\section{Effect of hot air temperature and layer thickness on drying kinetics of sludge}

The hot air experiments were conducted at the drying temperatures of 100,125 , and $150^{\circ} \mathrm{C}$ with layer thicknesses of 1 and 2 inch, and an airflow rate of $3 \mathrm{~m}^{3} / \mathrm{min}$. As shown in the drying curves in Fig. 2, the increase in temperature resulted in the decrease of drying time. The drying time of 1 and 2 inches of thickness decreased by 4 and $2 \mathrm{~h}$, respectively, when the drying temperatures were increased from 100 to $150^{\circ} \mathrm{C}$. An increase in drying temperature enhances the heat transfer of material that accelerates evaporation rate, mass transfer, and drying rate. Therefore, the moisture of the high-temperature conditions is evaporated rapidly than the low-temperature conditions (Zhang et al. 2016).

The varied thicknesses of the sludge layer were selected 1 and 2 inches. The results indicated that the moisture ratio of the sludge of 1 -inch thickness was reduced faster than the moisture ratio of the sludge of 2 -inch thickness. The drying time of the 1 -inch thickness of 150,125 , and $100{ }^{\circ} \mathrm{C}$ decreased by 45,38 , and $31 \%$, respectively, when compared with the 2 inch thickness. In hot air drying, heat is slowly transferred by convection (Paengkanya et al. 2015). The high layer thickness is slowly increased temperature, and water is slowly transferred from the inside to the surface of a material. Therefore, the thinner layer provides a higher drying rate than the thicker layer (Jafari et al. 2017).

The effects of the temperatures and the layer thicknesses on the drying time of sludge were calculated by using an analysis of variance (ANOVA) at a 0.95 confidence interval. The effect of the temperatures was insignificance with a P-value of 0.88 , which means that the variation of temperature between 100 to 150 ${ }^{\circ} \mathrm{C}$ was not much difference in the drying characteristics of the sludge. The effect of thickness of the sludge layers was significant with a P-value lower than 0.05 , which means that reducing layer thickness improved the drying characteristics of the sludge. The results indicated that layer thickness had a more significant effect on the drying characteristics of the sludge as compared to the hot air temperature. Nevertheless, in terms of the physical and chemical properties, the sludge temperature is most significant than the residence time (Poudel et al. 2015).

Effect of microwave power level on drying kinetics of sludge 
The microwave experiments were varied the microwave powers of $100,400,600$, and $800 \mathrm{~W}$ with the microwave power density of $0.25,1,1.5$, and $2 \mathrm{~W} / \mathrm{g}$, respectively. The drying curves of sludge during the microwave drying are shown in Fig. 3. The moisture ratio of the sludge decreased with a more slope when increasing the microwave power to $400-800 \mathrm{~W}$. The drying time of 400,600 , and $800 \mathrm{~W}$ decreased more than $83 \%$ compared to the drying time of $100 \mathrm{~W}$. It indicated that increasing the microwave power level contributed to a higher drying rate than the sludge dried by lower microwave power levels. Unlike conventional heating, the microwave has a high penetration into moist materials, which comprise polar and/or ionic molecules (Jafari et al. 2017). The high moisture content inside the sludge was able to absorb a greater amount of microwave energy from the high-power level, which led to volumetric heating generation in the sample. This enhanced to evaporate the moisture inside the material and reduced the drying time during the constant drying period. After the period, the drying rate decreased because the surface moisture became lower and the moisture from the inside layer decelerated to move to the surface. The agreeable results have previously been found by Apinyavisit et al. (2017), Bennamoun et al. (2016a), Nathakaranakule et al. (2019), Paengkanya et al. (2015), and Palamanit et al. (2019).

\section{Effect of microwave power level on sludge temperature}

The surface temperatures of sludge during the microwave experiment are shown in Fig. 4. The results of temperature variation presented the existence of the three main drying periods, namely adaptation period, constant rate period, and falling rate period. Similar results were obtained by Bennamoun et al. (2016a) and Mawioo et al. (2017). Their works studied microwave drying of sludge by varying microwave power levels.

The sludge surface temperature rapidly increased up to $80^{\circ} \mathrm{C}$ within the first $10 \mathrm{~min}$, especially 400,600 , and $800 \mathrm{~W}$ of microwave power. The high amounts of heat were generated by the interaction between the microwaves and dipolar molecule, which is the high concentration of water in the initial wet sludge (Barbosa de Lima et al. 2016). The temperature of 400-800 W of microwave power increased faster than $100 \mathrm{~W}$ of microwave power because when using the higher power level, more microwave energy was absorbed by the sample (Apinyavisit et al. 2017). However, the variation between $400-800 \mathrm{~W}$ reflected its almost no different effect during the adaptation period because the curves are almost overlapped.

In the constant rate period, most of the energy supplies to the evaporation of the water in the material, and the material temperature is almost constant (Mawioo et al. 2017). During this period constant temperature lines were around $10,20,30$, and $190 \mathrm{~min}$ for $800,600,400$, and $100 \mathrm{~W}$, respectively. The length of the period was varied by the microwave power levels. The higher power levels showed a shorter time, which indicated the simple trend of the power level effect.

In the falling drying rate period, the remained water in the material was slowly evaporated while it is still able to absorb the intensive microwave energy (Bennamoun et al. 2016a). Consequently, the temperature continued to increase until the end of the drying process. The sludge temperature for $100,400,600$, and $800 \mathrm{~W}$ of microwave levels increased up to $114,142,215$, and $204^{\circ} \mathrm{C}$, respectively. The sharp increase in the material temperature might be due to the phenomenon of thermal runaway (Ao et al. 2018; 
Apinyavisit et al. 2018; Barbosa de Lima et al. 2016; Gaukel et al. 2017). The phenomenon effect enhanced thermal degradation and the charring in the dried material. Moreover, the high temperature of the material probably affected in loss of product quality (Szadzińska et al. 2019). As presented in Fig. 1, the sludge temperatures beyond 120 and $200^{\circ} \mathrm{C}$ indicated organic matter decomposition and ignition point, respectively.

\section{Specific energy consumption of drying processes}

The SEC of different drying techniques for 1 inch of sludge layer thickness are presented in Fig. 5. SEC was calculated in terms of the amount of consumed energy in the processes with the corresponding weight of evaporated water of the sludge. The SEC of the microwave technique of $100,400,600$, and 800 W were $10.39,5.23,4.82$, and $4.62 \mathrm{MJ} / \mathrm{kg}$ of evaporated water, respectively, while the SEC of the hot air technique of 150,125 , and $100^{\circ} \mathrm{C}$ were $4.78,5.04$, and $6.03 \mathrm{MJ} / \mathrm{kg}$ of evaporated water, respectively. It can be seen that the $800 \mathrm{~W}$ condition saved the SEC about $3 \%$ as compared with the condition of $150{ }^{\circ} \mathrm{C}$. The SEC of hot air and microwave techniques were reduced with the increases in drying temperature and microwave power level, respectively. This is because both the increasing of the temperature and the power increase the drying rate and shorten the drying time. As seen that the shortest time of $800 \mathrm{~W}$ condition made the SEC lower than other conditions. Short drying time resulted in less SEC was found in various studies (Apinyavisit et al. 2017; Lao et al. 2019; Nathakaranakule et al. 2019; Paengkanya et al. 2015). However, the results of high SEC were due to limitations of the sludge load inside the ovens. As seen SEC of sludge drying of other studies in Table 2, the current results are still higher than the reviewed SEC for the conductive and convective commercial driers.

\section{Proximate analysis and energy values of dried sludge}

The dried sludge characteristics in terms of proximate analysis and energy values are shown in Table 3. The values of proximate analysis are presented on a dry ash-free basis to clearly compare the change of volatile matter and fixed carbon of the drying processes. The results of dried sludge at the hot air temperature of 100 and $125^{\circ} \mathrm{C}$ were not reported because (I) the temperature of $105^{\circ} \mathrm{C}$, which is about the same range of hot air experiment at $100^{\circ} \mathrm{C}$, was used as the standard method to dry the raw sludge for $24 \mathrm{~h}$; (II) as can be inferred from Fig. 1, the devolatilization effect did not vary much with the increase in sludge temperature from 105 to $125^{\circ} \mathrm{C}$. Therefore, the result of dried raw sludge was instead selected to compare with other conditions.

The results of the proximate analysis clearly show that the volatile matter of dried sludge under microwave and hot air techniques decreased as compared to the dried raw sludge under the standard condition at $105^{\circ} \mathrm{C}$ for $24 \mathrm{~h}$. The volatile matter reached the lowest level at $79.5 \%$ for $600 \mathrm{~W}$ of microwave power, whereas the fixed carbon increased up to $20.5 \%$ at the same condition. The decrease in the volatile matter was attributed to the increasing of the fixed carbon, that occurred due to the influence of sludge temperature during the processes (Kannan et al. 2017; Poudel et al. 2015). Besides the temperature effect, Yu and $\mathrm{Li}$ (2014) reported that the release of volatile was significantly influenced by microwave irradiation because of the increase in sludge surface porosity during microwave drying. 
As presented TG and DTG curves of the sludge in Fig. 1, it shows devolatilization and combustion phases are respectively located at the temperature range of $120-200^{\circ} \mathrm{C}$ and $200-900^{\circ} \mathrm{C}$. The sludge temperatures of microwave techniques (Fig. 4) reached the devolatilization zone, especially the microwave power of $600 \mathrm{~W}$ that showed the highest temperature at $215^{\circ} \mathrm{C}$. In the case of hot air drying at $150^{\circ} \mathrm{C}$, the decrease in volatile matter indicated that the sludge temperature reached the devolatilization zone. Following theoretical hot-air drying, the temperature of materials finally increases to reach the dry-bulb temperature of the hot air (Devahastin 2012), which was about $150^{\circ} \mathrm{C}$ in this case.

The fuel characteristics of the dried sludge could be indicated by the "Fuel ratio", which is the ratio of fixed carbon per volatile matter (Kannan et al. 2017). The fuel ratio of dried sludge under both techniques were slightly higher than the fuel ratio of raw sludge. The increase in fuel ratio normally represents improved fuel characteristics of the product, due to the decreasing of volatile matter. Nevertheless, in the case of the sludge, it affected the decrease in calorific value. GCV of the dried sludge of microwave and hot air techniques decreased up to $5 \%$ when compared with the raw sludge. The GCV exhibited a relative change with volatile matter content. For instance, the raw sludge revealed the highest volatile matter and highest GCV, while the dried sludge of $600 \mathrm{~W}$ revealed the lowest volatile matter and lowest GCV. This is because volatile matter represented the main combustible matter in the sludge. The proportion of volatile matter in the sludge was higher than fixed carbon about three times. When the sludge temperature increased, the volatile matter easily decomposed and led to a decrease in the GCV. Similar trends were observed in the studies of Mawioo et al. (2017). The energy densification in dried sludge could be calculated in terms of the "Energy enrichment factor", which is the ratio of calorific value of dried sludge per calorific value of the raw sludge (Kannan et al. 2017). All dried sludge of microwave and hot air techniques showed the value of energy enrichment factor lower than 1 , indicating the decrease in energy densification of product. This decrease in energy enrichment factor is attributed to the decreasing of GCV. However, the lowest GCV obtained in this study $(20.8 \mathrm{MJ} / \mathrm{kg})$ is comparable to the GCV of other sludge as 14-23 MJ/kg (He et al. 2013; Mawioo et al. 2017; Poudel et al. 2015), lignite as 12-25 MJ/kg (Arlabosse et al. 2011; Syed-Hassan et al. 2017; Zhang et al. 2016), and bituminous as 21-29 MJ/kg (ASTM International 2019; Syed-Hassan et al. 2017).

The calorific values of the dried sludge were comparatively higher than the SEC during the processes. Mawioo et al. (2017) suggest that the sludge could be looking forward to recovering the energy as use as RDF. However, the combustion properties of dried sludge need to be further studied to prove whether the dried sludge could be an alternative solid fuel. In addition, the drying cost needs to be further assessed in the pilot and industrial scales.

\section{Elemental analysis of dried sludge}

The results of the elemental analysis of the dried sludge are shown in Table 4. Inferring to the high values of GCV and energy enrichment factor, which are advantages for using the dried sludge as solid fuel, the elemental analysis was done for the dried sludge at $150^{\circ} \mathrm{C}$ of hot air temperature and $800 \mathrm{~W}$ of microwave power. The results of dried sludge at $150{ }^{\circ} \mathrm{C}$ show an increase in $\mathrm{C}$ and $\mathrm{N}$ proportion when 
compared with the raw sludge. In contrast, the proportion of $\mathrm{H}$ and $\mathrm{O}$ were decreased. As usual, the decreasing of hydrogen and oxygen contents is influenced by dehydration of biomass (Poudel et al. 2015). The increase in carbon and nitrogen contents were relatively increased due to the fact that the other elements were decreased. The dried sludge at $800 \mathrm{~W}$ shows the apparent decrease in $\mathrm{C}$ proportion, because of the overheating problem. The sludge temperature increased up to $204^{\circ} \mathrm{C}$ indicating the combustion (Fig. 1) at the falling period of the microwave drying. Further studies are required to prevent this phenomenon. The proportion of $\mathrm{O}$ and $\mathrm{S}$ followed an opposite tendency when compared with the change of the carbon content. $\mathrm{H} / \mathrm{C}$ and $\mathrm{O} / \mathrm{C}$ ratios were calculated for an understanding of the occurred reactions that might affect solid fuel production from the sludge. The $\mathrm{H} / \mathrm{C}$ ratio of both dried sludge at $150^{\circ} \mathrm{C}$ and $800 \mathrm{~W}$ were lower than the raw sludge because of the dehydration reaction during the process (He et al. 2013; Kannan et al. 2017). The O/C ratio slightly decreased for the hot air temperature of 150 ${ }^{\circ} \mathrm{C}$. The change in the $\mathrm{O} / \mathrm{C}$ ratio was described by Poudel et al. (2015). The decrease in the $\mathrm{O} / \mathrm{C}$ ratio is related to the formation of volatiles rich in oxygen. For the dried sludge at $800 \mathrm{~W}$, the $\mathrm{O} / \mathrm{C}$ ratio was higher than the raw sludge. This represented the occurrence of decarboxylation reaction (Kannan et al. 2017).

\section{Conclusion}

This study investigated the characteristics of dewatered sludge and the drying using microwave and hot air techniques. The drying experiments of the dewatered sludge were conducted at microwave power levels of $100-800 \mathrm{~W}$ and hot air temperatures of $100-150^{\circ} \mathrm{C}$. Characteristics of raw sludge were analyzed in chemical and calorific properties. The raw sludge showed high initial moisture content of $87 \%$ (wet basis), but the GCV was higher than $21 \mathrm{MJ} / \mathrm{kg}$. The high amount of volatile matter of the sludge influenced the low ignition temperature at $200^{\circ} \mathrm{C}$. In terms of the thermal degradation, TG and DTG curves of raw sludge indicated the devolatilization phase around a temperature higher than $120^{\circ} \mathrm{C}$. In the drying process of sludge, the temperatures of devolatilization and combustion steps are the important keys for solid fuel production. Results of the drying experiment were investigated the drying kinetics, the SEC of each technique, and the dried sludge properties. The experimental results of varied thicknesses of the sludge during the hot air drying showed that drying time decreased more than $30 \%$ by decreasing the layer thickness of sludge. The microwave technique showed positive effects on the drying kinetics and accelerated the evaporation of water in the sludge. The application of microwaves reduced the drying times by more than $46 \%$ compared to the hot air technique. The drying time decreased with the increase of the microwave power level or hot air temperature due to higher drying rates. The reduction of drying time resulted in the saving SEC of the drying processes. The low SEC were in the same range as 4.6-4.8 $\mathrm{MJ} / \mathrm{kg}$ of evaporated water for hot air condition at $150^{\circ} \mathrm{C}$ and microwave condition at 600-800 W. Microwave and hot air techniques affected the dried sludge properties. The fuel ratio of dried sludge increased up to 0.26 , which was higher than the raw sludge, because of the decrease in volatile matter and the increase in fixed carbon of the sludge. However, the loss of volatile matter in the dried products mainly influenced the decrease in GCV as 0.95-0.99 times of the raw sludge. The microwave technique showed the GCV lower than the hot air technique due to the overheating problem, which exhibited the maximum temperature of the sludge up to $215^{\circ} \mathrm{C}$. The decrease in carbon proportion of the dried sludge 
by using the microwave power of $800 \mathrm{~W}$ represented the occurrence of decarboxylation reaction as seen in the $\mathrm{O} / \mathrm{C}$ ratio higher than the raw sludge. The occurrence of dehydration reaction was represented by the slight decrease in the $\mathrm{H} / \mathrm{C}$ ratio of both techniques. According to the studied results, the dried sludge of both techniques was almost in the same range of the product characteristics. The microwave and hot air techniques can produce the dried sludge with high GCV comparable to lignite and bituminous. For fuel characteristic aspects observed in the study, the dried sludge has the potential for recovery and reuse for energy applications such as alternative solid fuel by co-combustion with coal. Considering in terms of the drying time saving and productivity, the microwave technique found to be an attractive benefit for drying sludge as compared to conventional drying by hot air technique. Under the conditions of this experiment, the lowest drying time, lowest SEC, and high GCV of the dried sludge were observed in the drying condition of $800 \mathrm{~W}$. However, the prevention or reduction of thermal degradation during microwave drying should be studied further to improve the qualities of dried product.

\section{Declarations}

Funding: King Mongkut's University of Technology Thonburi, and The National Research Council of Thailand

Conflicts of interest/Competing interests: No

Availability of data and material: NA

Code availability: NA

Authors' contributions: NA

\section{Acknowledgments}

The authors would like to express their gratitude to The Joint Graduate School of Energy and Environment (JGSEE), King Mongkut's University of Technology Thonburi and the Center of Excellence on Energy Technology and Environment (CEE), PERDO, Ministry of Higher Education, Science, Research and Innovation for the financial support provided to perform this study.

\section{Compliance with ethical standards}

Conflict of interest The authors declare that they have no conflict of interests.

\section{References}

1. Ao W et al. (2018) Microwave assisted preparation of activated carbon from biomass: A review Renewable and Sustainable Energy Reviews 92:958-979 doi:10.1016/j.rser.2018.04.051

2. Apinyavisit K, Nathakaranakule A, Mittal GS, Soponronnarit S (2018) Heat and mass transfer properties of longan shrinking from a spherical to an irregular shape during drying Biosystems 
Engineering 169:11-21 doi:10.1016/j.biosystemseng.2018.01.007

3. Apinyavisit K, Nathakaranakule A, Soponronnarit S, Mittal GS (2017) A Comparative Study of Combined Microwave Techniques for Longan (Dimocarpus longan Lour.) Drying with Hot Air or Vacuum International Journal of Food Engineering 13 doi:10.1515/ijfe-2016-0263

4. Arlabosse P, Ferrasse JH, Lecomte D, Crine M, Dumont Y, Léonard A (2011) Efficient sludge thermal processing: from drying to thermal valorization. In: Modern Drying Technology: Volume 4: Energy Savings, vol 4. pp 295-329

5. ASTM International (2016) Standard Test Methods for Determination of Carbon, Hydrogen and Nitrogen in Analysis Samples of Coal and Carbon in Analysis Samples of Coal and Coke.

6. ASTM International (2017) Standard Test Method for Moisture in the Analysis Sample of Coal and Coke vol D3173/D3173M-17a. doi:10.1520/d3173_d3173m-17a

7. ASTM International (2019) Standard guide for use of scrap tires as tire-derived fuel vol D6700-19. ASTM International, West Conshohocken, PA. doi:10.1520/d6700-19

8. Barbosa de Lima AG, Delgado JMPQ, Silva EG, de Farias Neto SR, Santos JPS, de Lima WMPB (2016) Drying Process in Electromagnetic Fields. In: Delgado JMPQ, Barbosa de Lima AG (eds) Drying and Energy Technologies. Springer International Publishing, Cham, pp 89-110. doi:10.1007/978-3-319-19767-8_5

9. Bennamoun L, Chen Z, Afzal MT (2016a) Microwave drying of wastewater sludge: Experimental and modeling study Drying Technology 34:235-243 doi:10.1080/07373937.2015.1040885

10. Bennamoun L, Fraikin L, Li J, Léonard A (2016b) Forced Convective Drying of Wastewater Sludge with the Presentation of Exergy Analysis of the Dryer Chemical Engineering Communications 203:855-860 doi:10.1080/00986445.2015.1114475

11. Bundhoo ZMA (2018) Microwave-assisted conversion of biomass and waste materials to biofuels Renewable and Sustainable Energy Reviews 82:1149-1177 doi:10.1016/j.rser.2017.09.066

12. Darvishi H, Azadbakht M, Rezaeiasl A, Farhang A (2013) Drying characteristics of sardine fish dried with microwave heating Journal of the Saudi Society of Agricultural Sciences 12:121-127 doi:10.1016/j.jssas.2012.09.002

13. Devahastin S (2012) Drying of foods and biomaterials. Top Publishing, Bangkok, Thailand

14. Fennell LP, Boldor D (2014) Continuous microwave drying of sweet sorghum bagasse biomass Biomass and Bioenergy 70:542-552 doi:10.1016/j.biombioe.2014.08.012

15. Gaukel V, Siebert T, Erle U (2017) Microwave-assisted drying. In: The Microwave Processing of Foods. pp 152-178. doi:10.1016/b978-0-08-100528-6.00008-5

16. He C, Giannis A, Wang J-Y (2013) Conversion of sewage sludge to clean solid fuel using hydrothermal carbonization: Hydrochar fuel characteristics and combustion behavior Applied Energy 111:257-266 doi:10.1016/j.apenergy.2013.04.084

17. Hong SM, Park JK, Teeradej N, Lee YO, Cho YK, Park CH (2006) Pretreatment of sludge with microwaves for pathogen destruction and improved anaerobic digestion performance Water Environ 
Res 78:76-83 doi:10.2175/106143005x84549

18. Jafari $H$, Kalantari D, Azadbakht M (2017) Semi-industrial continuous band microwave dryer for energy and exergy analyses, mathematical modeling of paddy drying and it's qualitative study Energy 138:1016-1029 doi:10.1016/j.energy.2017.07.111

19. Jong Wd, Ommen JRv (2015) Biomass as a sustainable energy source for the future : fundamentals of conversion processes. John Wiley \& Sons, Inc., the United States of America

20. Kannan S, Gariepy Y, Raghavan GSV (2017) Optimization and characterization of hydrochar produced from microwave hydrothermal carbonization of fish waste Waste Manag 65:159-168 doi:10.1016/j.wasman.2017.04.016

21. Karlsson M, Carlsson H, Idebro M, Eek C (2019) Microwave Heating as a Method to Improve Sanitation of Sewage Sludge in Wastewater Plants IEEE Access 7:142308-142316 doi:10.1109/access.2019.2944210

22. Kijo-Kleczkowska A, Środa K, Kosowska-Golachowska M, Musiał T, Wolski K (2016) Combustion of pelleted sewage sludge with reference to coal and biomass Fuel 170:141-160 doi:10.1016/j.fuel.2015.12.026

23. Lao Y, Zhang M, Devahastin S, Ye Y (2019) Effect of combined infrared freeze drying and microwave vacuum drying on quality of kale yoghurt melts Drying Technology 38:621-633 doi:10.1080/07373937.2019.1658600

24. Li J, Fraikin L, Salmon T, Bennamoun L, Toye D, Schreinemachers R, Léonard A (2015) Investigation on Convective Drying of Mixtures of Sewage Sludge and Sawdust in a Fixed Bed Drying Technology 33:704-712 doi:10.1080/07373937.2014.982254

25. Liu Z, Wang HQ, Zhang XD, Liu JW, Zhou YY (2017) Dechlorination of organochloride waste mixture by microwave irradiation before forming solid recovered fuel Waste Manag 62:118-124 doi:10.1016/j.wasman.2016.11.022

26. Lu J-J, Chen W-H (2015) Investigation on the ignition and burnout temperatures of bamboo and sugarcane bagasse by thermogravimetric analysis Applied Energy 160:49-57 doi:10.1016/j.apenergy.2015.09.026

27. Lu S et al. (2013) Atmospheric emission characterization of a novel sludge drying and cocombustion system Journal of Environmental Sciences 25:2088-2092 doi:10.1016/s10010742(12)60272-1

28. Mawioo PM, Garcia HA, Hooijmans CM, Velkushanova K, Simonic M, Mijatovic I, Brdjanovic D (2017) A pilot-scale microwave technology for sludge sanitization and drying Sci Total Environ 601602:1437-1448 doi:10.1016/j.scitotenv.2017.06.004

29. Mokhtar N, Omar R, Salleh MM, Idris A (2011) Characterization of sludge from the wastewatertreatment plant of a refinery International Journal of Engineering and Technology 8:48-56

30. Mounir S, Amami E, Allaf T, Mujumdar A, Allaf K (2019) Instant controlled pressure drop (DIC) coupled to intermittent microwave/airflow drying to produce shrimp snacks: Process performance and quality attributes Drying Technology 38:695-711 doi:10.1080/07373937.2019.1694537 
31. Nathakaranakule A, Paengkanya S, Soponronnarit S (2019) Durian chips drying using combined microwave techniques with step-down microwave power input Food and Bioproducts Processing doi:10.1016/j.fbp.2019.04.010

32. Nzihou A (2020) Handbook on Characterization of Biomass, Biowaste and Related By-products. 1 edn. Springer International Publishing, Cham, Switzerland. doi:10.1007/978-3-030-35020-8

33. Paengkanya S, Soponronnarit S, Nathakaranakule A (2015) Application of microwaves for drying of durian chips Food and Bioproducts Processing 96:1-11 doi:10.1016/j.fbp.2015.06.001

34. Palamanit A, Musengimana Sugira A, Soponronnarit S, Prachayawarakorn S, Tungtrakul P, Kalkan F, Raghavan V (2019) Study on quality attributes and drying kinetics of instant parboiled rice fortified with turmeric using hot air and microwave-assisted hot air drying Drying Technology:1-14 doi:10.1080/07373937.2019.1579735

35. Parshetti GK, Liu Z, Jain A, Srinivasan MP, Balasubramanian R (2013) Hydrothermal carbonization of sewage sludge for energy production with coal Fuel 111:201-210 doi:10.1016/j.fuel.2013.04.052

36. Phongphiphat A, Towprayoon S, Winijkul A (2020) Alternative fuels production utilizing dewatered sludge from seafood processing industry. The Joint Graduate School of Energy and Environment, King Mongkut's University of Technology Thonburi., Bangkok, Thailand.

37. Poudel J, Ohm TI, Lee SH, Oh SC (2015) A study on torrefaction of sewage sludge to enhance solid fuel qualities Waste Manag 40:112-118 doi:10.1016/j.wasman.2015.03.012

38. Syed-Hassan SSA, Wang Y, Hu S, Su S, Xiang J (2017) Thermochemical processing of sewage sludge to energy and fuel: Fundamentals, challenges and considerations Renewable and Sustainable Energy Reviews 80:888-913 doi:10.1016/j.rser.2017.05.262

39. Szadzińska J, Mierzwa D, Pawłowski A, Musielak G, Pashminehazar R, Kharaghani A (2019) Ultrasound- and microwave-assisted intermittent drying of red beetroot Drying Technology 38:93-107 doi:10.1080/07373937.2019.1624565

40. Tańczuk M, Kostowski W, Karaś M (2016) Applying waste heat recovery system in a sewage sludge dryer - A technical and economic optimization Energy Conversion and Management 125:121-132 doi:10.1016/j.enconman.2016.02.064

41. Thai tuna industry association (2020) World top 10 exporters and importer of tuna products in 20172019. Thai tuna industry association. www.thaituna.org/home/annual-report.php. Accessed 14 May 20202020

42. Villagracia ARC et al. (2016) Microwave drying characteristics of microalgae (Chlorella vulgaris) for biofuel production Clean Technologies and Environmental Policy 18:2441-2451 doi:10.1007/s10098016-1169-0

43. Wang Y, Xiao Q, Liu J, Yan H, Wei Y (2015) Pilot-scale study of sludge pretreatment by microwave and sludge reduction based on lysis-cryptic growth Bioresour Technol 190:140-147 doi:10.1016/j.biortech.2015.04.046

44. Yu LY, Li PS (2014) Thermogravimetric analysis of coal and sludge co-combustion with microwave radiation dehydration Journal of the Energy Institute 87:220-226 doi:10.1016/j.joei.2014.03.009 
45. Záleská M et al. (2017) Biomass ash-based mineral admixture prepared from municipal sewage sludge and its application in cement composites Clean Technologies and Environmental Policy 20:159-171 doi:10.1007/s10098-017-1465-3

46. Zhang XY, Chen MQ, Huang YW, Xue F (2016) Isothermal hot air drying behavior of municipal sewage sludge briquettes coupled with lignite additive Fuel 171:108-115 doi:10.1016/j.fuel.2015.12.052

47. Zohrabi S, Seiiedlou SS, Aghbashlo M, Scaar H, Mellmann J (2019) Enhancing the exergetic performance of a pilot-scale convective dryer by exhaust air recirculation Drying Technology 38:518533 doi:10.1080/07373937.2019.1587617

\section{Tables}

Table 1 Characteristics of the raw sludge

\begin{tabular}{|ll|}
\hline Characteristics & Mean \pm SD \\
\hline Moisture content (wt\%, wet basis) & $87.40 \pm 0.15$ \\
\hline Proximate analysis (wt\%, dry basis) & \\
\hline Volatile matter (VM) & $73.04 \pm 3.97$ \\
\hline Fixed carbon (FC) & $15.77 \pm 3.45$ \\
\hline Ash & $11.19 \pm 0.51$ \\
\hline Elemental analysis (wt\%, dry basis) & \\
\hline C & $46.75 \pm 3.13$ \\
\hline H & $7.25 \pm 0.58$ \\
\hline N & $7.43 \pm 0.51$ \\
\hline S & $1.69 \pm 0.19$ \\
\hline O & $25.69 \pm 2.87$ \\
\hline GCV (MJ/kg, dry basis) & $21.92 \pm 2.35$ \\
\hline
\end{tabular}

Table 2 Specific energy consumption of sludge drying 


\begin{tabular}{|lll|}
\hline Drying technique & SEC $(\mathrm{MJ} / \mathrm{kg})$ & Reference \\
\hline Microwave drying & $10.2-16.7$ & Mawioo et al. (2017) \\
\hline Convective drying & & Arlabosse et al. (2011) \\
\hline Belt dryer & $2.5-4.1$ & \\
\hline Drum dryer & $3.2-4.0$ & \\
\hline Flash dryer & $4.3-5.0$ & \\
\hline Conductive drying & & Bennamoun et al. (2016a) \\
\hline Disc dryer & $3.1-3.4$ & \\
\hline Paddle dryer & $2.9-3.2$ & \\
\hline Thin film dryer & $2.9-3.3$ & \\
\hline
\end{tabular}

Table 3 Proximate analysis and energy values of dried sludge

\begin{tabular}{|lllllll|}
\hline Characteristic & \multicolumn{2}{l}{ Microwave } & \multicolumn{3}{c}{ Hot air } & Raw sludge \\
\cline { 2 - 6 } & $100 \mathrm{~W}$ & $400 \mathrm{~W}$ & $600 \mathrm{~W}$ & $800 \mathrm{~W}$ & $150^{\circ} \mathrm{C}$ & \\
\cline { 1 - 2 } $\begin{array}{l}\text { Proximate analysis } \\
\text { (wt\%, dry ash-free basis) }\end{array}$ & & & & & & \\
VM & 79.90 & 80.32 & 79.48 & 80.34 & 80.27 & 82.24 \\
\hline FC & 20.10 & 19.68 & 20.52 & 19.66 & 19.73 & 17.76 \\
\hline Fuel ratio & 0.25 & 0.25 & 0.26 & 0.24 & 0.25 & 0.22 \\
\hline Energy value & & & & & & \\
\hline GCV (MJ/kg) & 20.94 & 20.86 & 20.80 & 21.39 & 21.81 & 21.92 \\
\hline Energy enrichment factor & 0.96 & 0.95 & 0.95 & 0.98 & 0.99 & 1.00 \\
\hline
\end{tabular}

Table 4 Elemental analysis of dried sludge 


\begin{tabular}{|c|c|c|c|c|c|c|c|}
\hline \multirow[t]{2}{*}{ Case } & \multicolumn{5}{|c|}{ Elemental analysis (wt\%, dry ash-free basis) } & \multirow[t]{2}{*}{$\mathrm{H} / \mathrm{C}$ ratio } & \multirow[t]{2}{*}{$\mathrm{O} / \mathrm{C}$ ratio } \\
\hline & C & $\mathrm{H}$ & $\mathrm{N}$ & S & 0 & & \\
\hline Raw sludge & 52.64 & 8.16 & 8.37 & 1.90 & 28.93 & 0.16 & 0.55 \\
\hline Dried at $150{ }^{\circ} \mathrm{C}$ & 53.27 & 7.99 & 8.65 & 1.36 & 28.73 & 0.15 & 0.54 \\
\hline Dried at $800 \mathrm{~W}$ & 50.86 & 7.88 & 8.38 & 2.02 & 30.86 & 0.15 & 0.61 \\
\hline
\end{tabular}

Figures

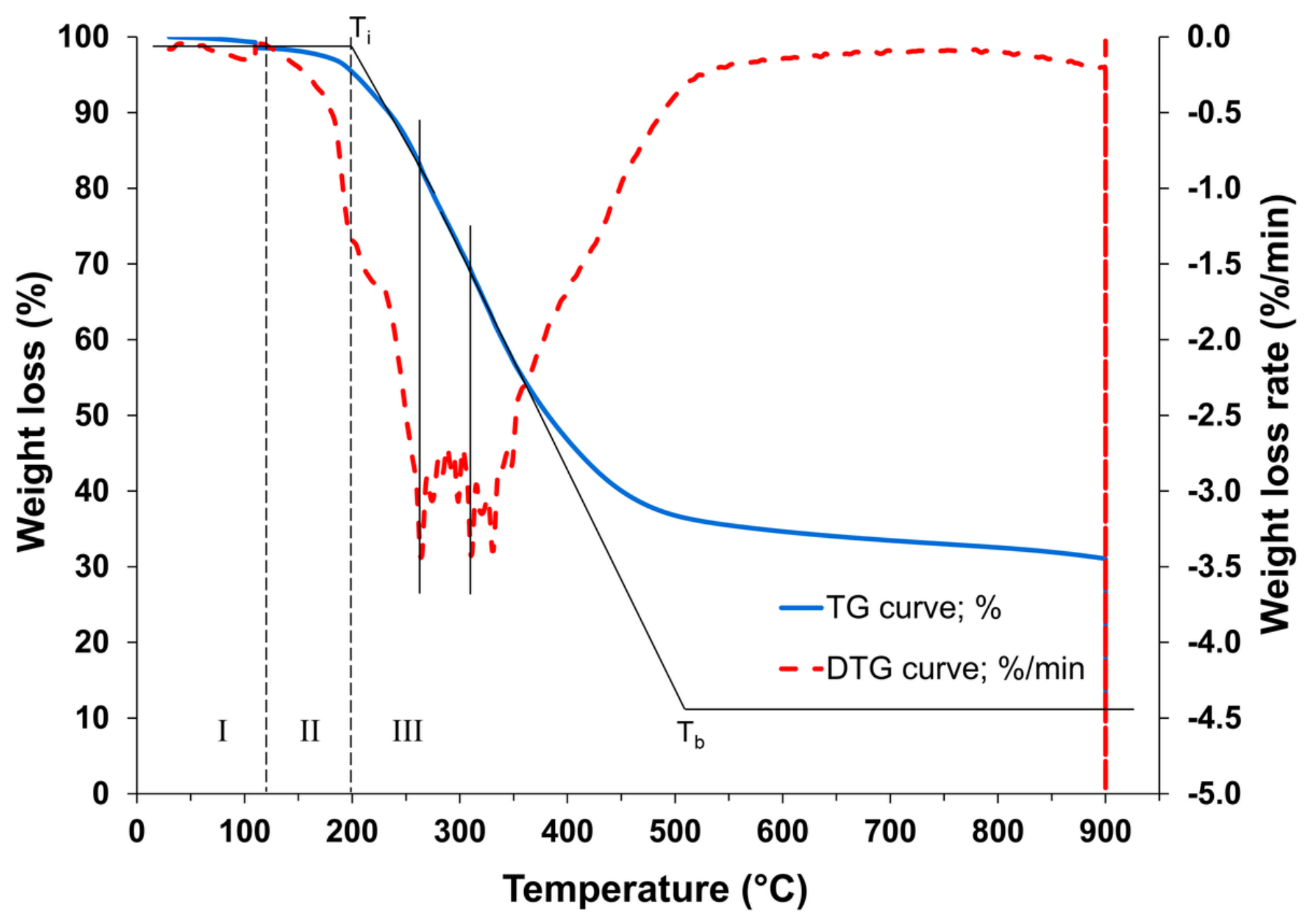

Figure 1

TG and DTG curves of the raw sludge; (I) evaporation, (II) devolatilization, (III) combustion 


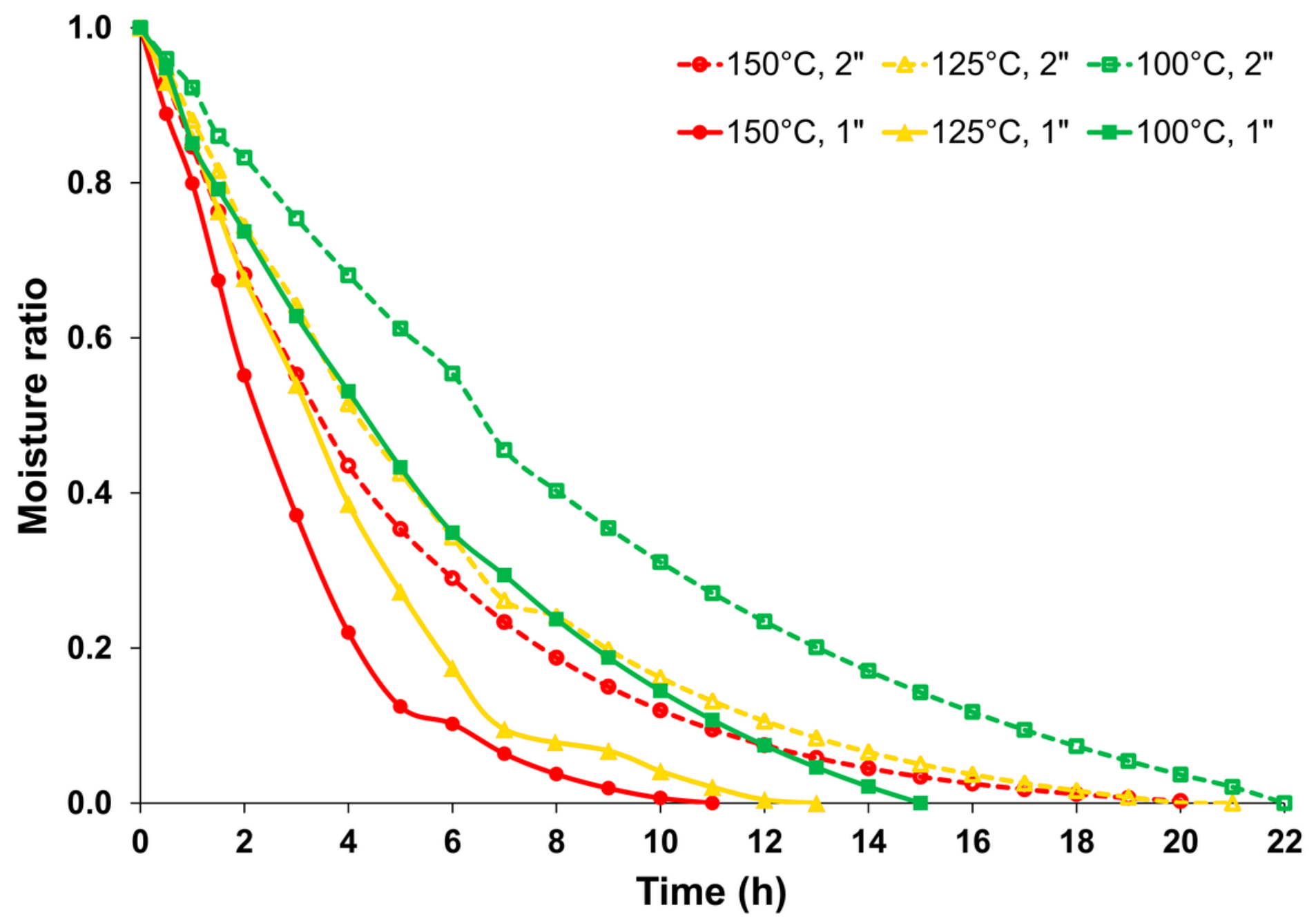

Figure 2

Variation of moisture ratio of sludge during drying with hot air technique 


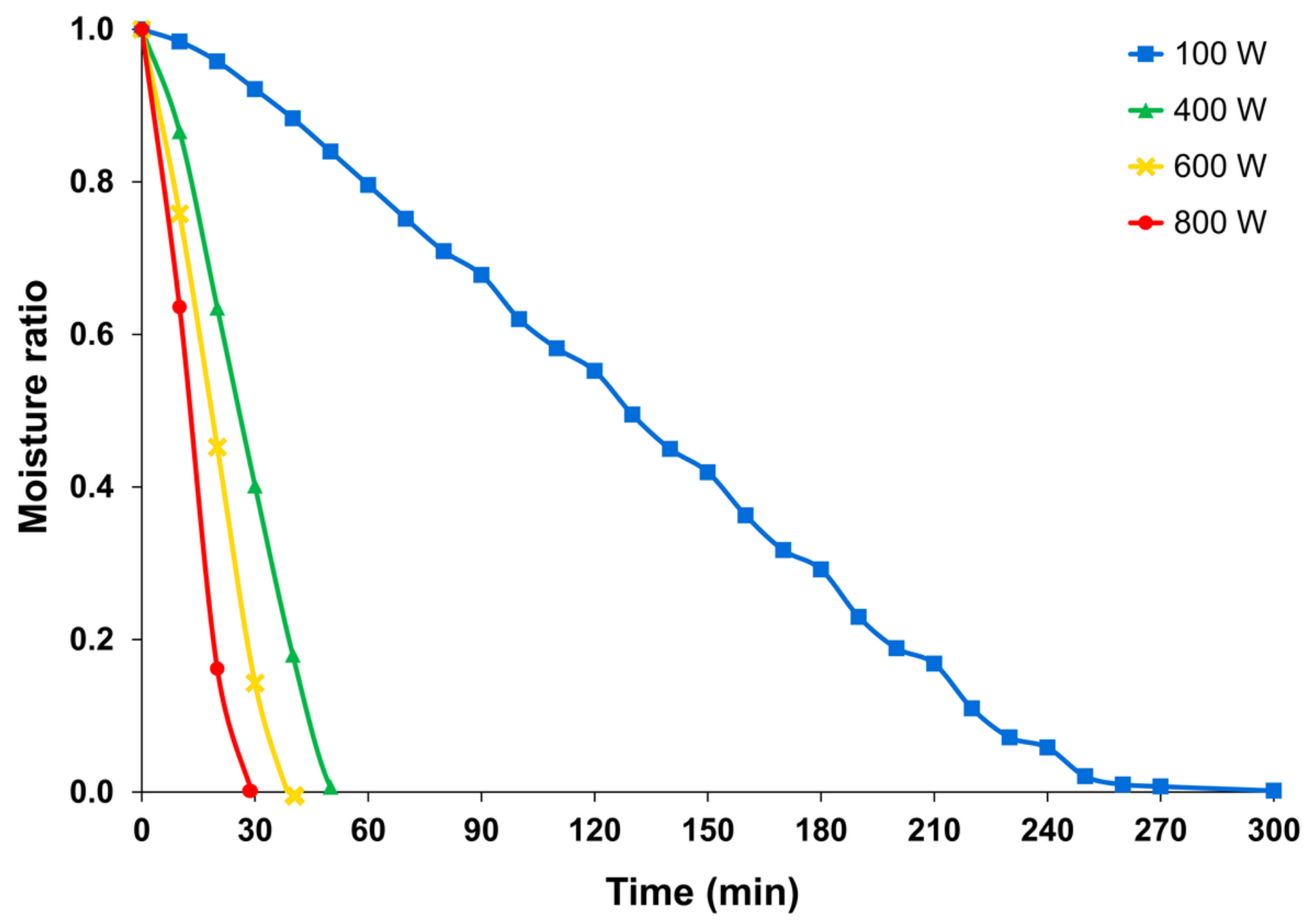

Figure 3

Variation of moisture ratio of sludge during drying with microwave technique 


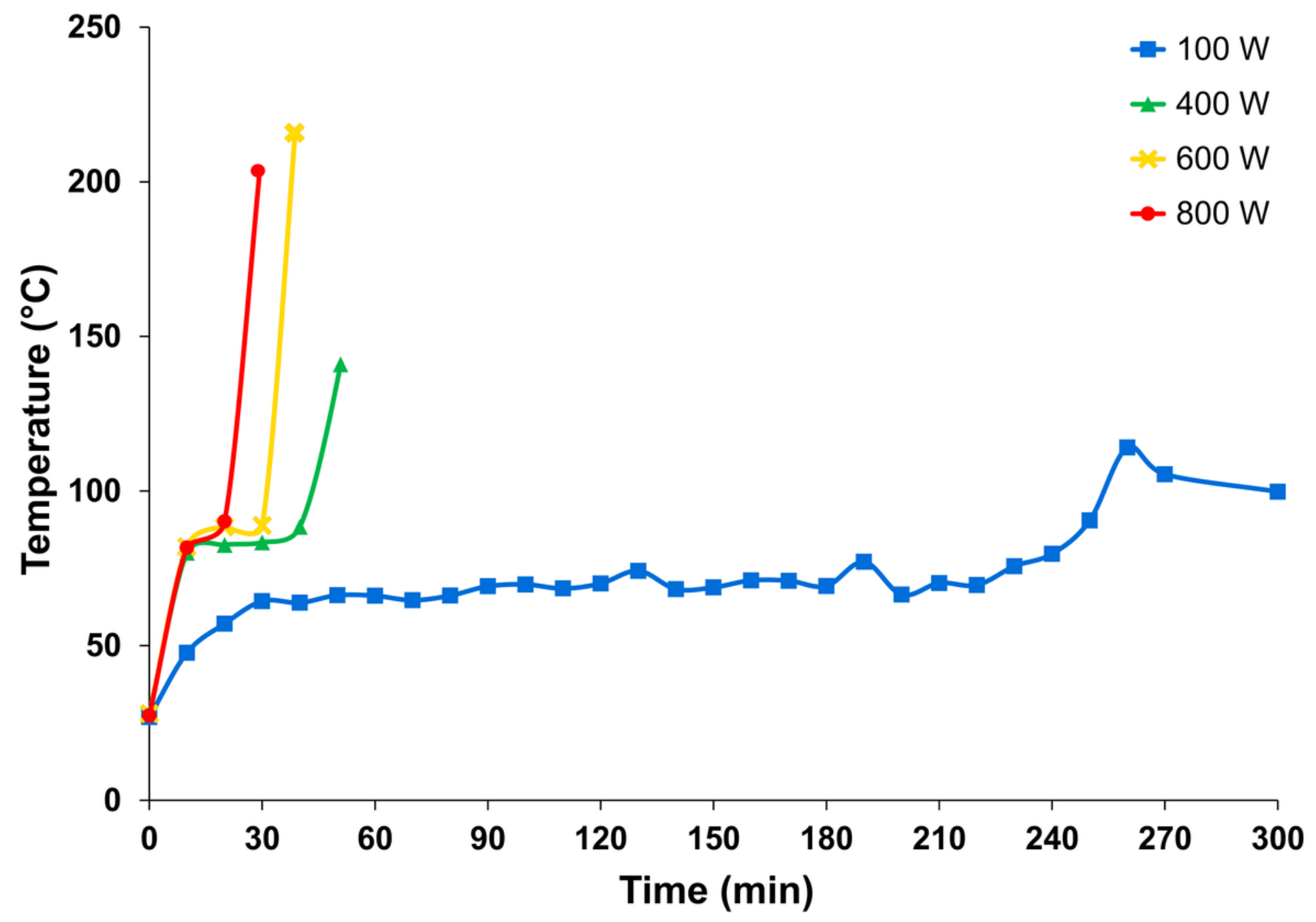

Figure 4

Temperature of sludge during drying with microwave technique 


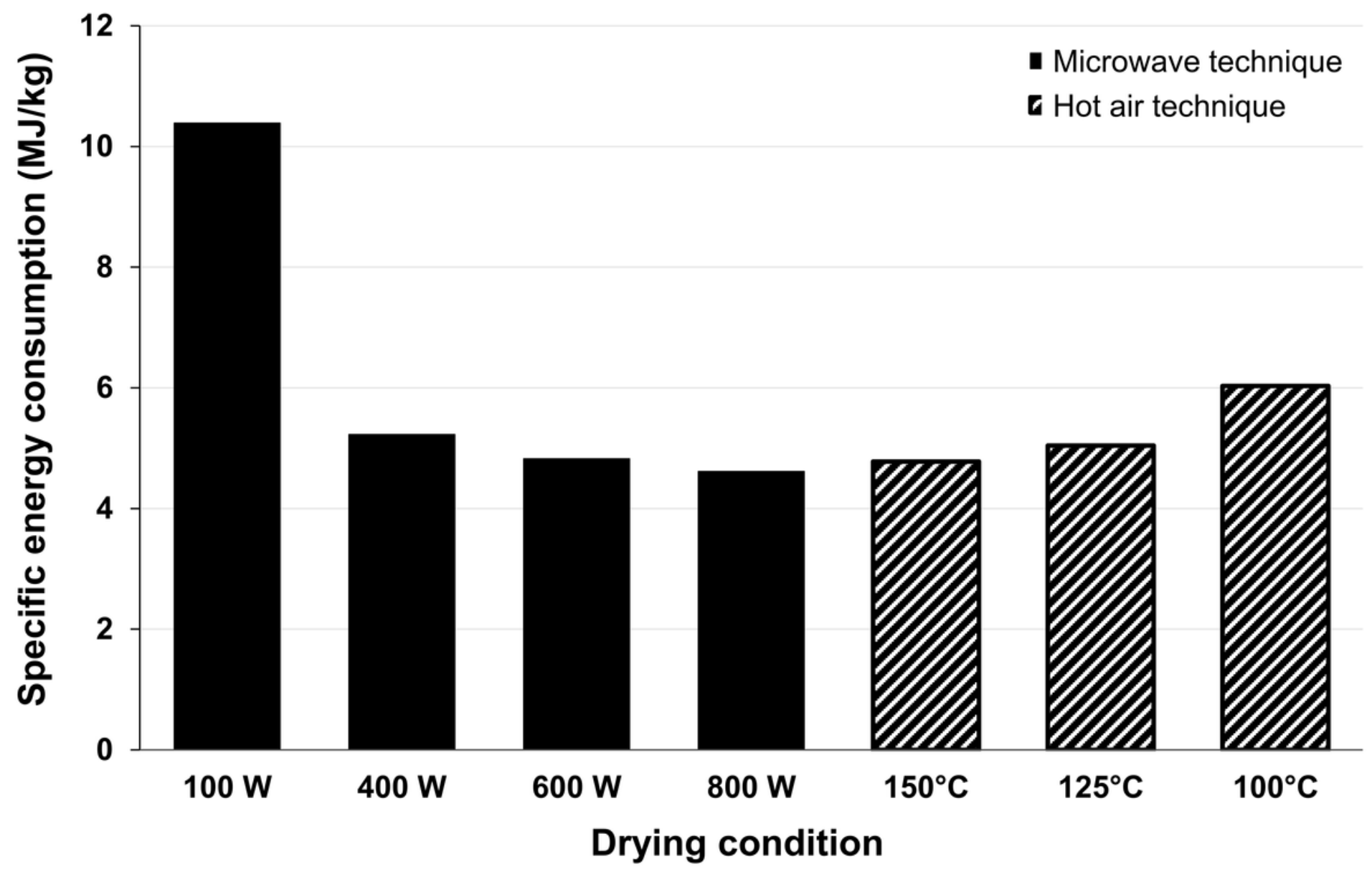

Figure 5

Specific energy consumption of different drying techniques for 1 inch of sludge layer thickness 